\title{
Response of Maize (Zea mays L.) to Different Rates of Palm Bunch Ash Application in the Semi-deciduous Forest Agro-ecological Zone of Ghana
}

\author{
S. Adjei-Nsiah \\ Forest and Horticultural Crops Research Centre, Institute of Agricultural Research, College of Agriculture and Consumer Sciences, \\ University of Ghana, P.O. Box 68, Legon, Ghana \\ Correspondence should be addressed to S. Adjei-Nsiah, y_nsiah@yahoo.co.uk
}

Received 15 November 2011; Accepted 2 January 2012

Academic Editor: Rosario García Moreno

Copyright () 2012 S. Adjei-Nsiah. This is an open access article distributed under the Creative Commons Attribution License, which permits unrestricted use, distribution, and reproduction in any medium, provided the original work is properly cited.

The effects of palm bunch ash (PBA) and mineral fertilizer application on grain yield and nutrient uptake in maize and soil chemical properties were studied in both the major and minor rainy seasons in the semi-deciduous forest agro-ecological zone of Ghana. In both the major and minor rainy seasons, the response of maize to four levels $(0,2,4$, and 6 tons per hectare) of palm bunch ash and $200 \mathrm{~kg}$ per hectare of NPK (15-15-15) application was evaluated using randomised complete block design. Results of the study showed that application of palm bunch ash significantly $(P<0.05)$ increased soil pH, soil phosphorus, and exchangeable cations. Maize grain yield varied significantly $(P<0.05)$ among the different treatments in both the major and minor rainy seasons. The highest maize grain yield of 4530 and $6120 \mathrm{~kg} \mathrm{ha}^{-1}$ was obtained at PBA application rate of 2 tons ha ${ }^{-1}$ for the major and minor rainy seasons, respectively.

\section{Introduction}

Empty fruit bunch (EFB) is one of the major waste products generated from processing fresh fruit bunch (FFB) in palm fruit processing mills. About $22 \%$ of FFB processed into oil end up as EFB [1]. Currently, Ghana produces about $1,900,000$ metric tons of FFB annually [2] which, when processed into oil, generate 418,000 MT of EFB annually. In the large industrial estates, EFB is either incinerated in the mills as a means of getting rid of these wastes' as well as, providing energy for the boilers in FFB sterilization. However, the small-scale mills which process about $60 \%$ of the total FFB produced in the country [3] burn the EFB as a means of disposing them, resulting in heaps of ash dotted around small-scale mills in the major oil palm producing areas in Ghana. There is currently no large-scale use for palm bunch ash in Ghana, although it could be used for the manufacture of local soap due to its high potassium content. The palm bunch ash (PBA) produced by burning EFB, which constitutes about $6.5 \%$ by weight of the EFB, contains 30 $40 \% \mathrm{~K}_{2} \mathrm{O}[1]$ and could thus be used as source of potassium fertilizer. Most soils in the forest part of southern Ghana where oil palm is cultivated are acidic due to the nature of the parent material, high rainfall regime, intensity, and associated leaching of nutrients which requires sustainable liming. Preliminary analysis of bunch ash of different ages from processing mills in Kade (unpublished results) indicates that besides $\mathrm{K}$, palm bunch ash has high $\mathrm{pH}$ and contains varying amounts of other nutrients such as calcium $(\mathrm{Ca})$, phosphorus $(\mathrm{P})$, and magnesium $(\mathrm{Mg})$. These properties of palm bunch ash make it suitable as a liming material and fertilizer supplement. Studies [4-6] have shown that application of wood ash significantly increased the effective cation exchange capacity and base saturation and decreased the concentration of exchangeable aluminium in the soil. In southern Nigeria, [7] and [8] found palm bunch ash as an effective fertilizer and liming material for increasing soil fertility, $\mathrm{pH}$, and nutrient uptake by crops such as maize and cassava.

In Ghana, mineral fertilizers are rarely used by smallholder farmers due to prohibitive cost as a result of privatization and removal of government subsidies [9]. In recent 
TABLE 1: Chemical and physical soil characteristics of surface soil $(0-20 \mathrm{~cm})$ of experimental plots before planting.

\begin{tabular}{|c|c|c|c|c|c|c|c|c|c|c|c|}
\hline $\begin{array}{l}\mathrm{pH} \\
\left(1: 1 \mathrm{H}_{2} \mathrm{o}\right)\end{array}$ & $\begin{array}{c}\text { OC } \\
\% \\
\end{array}$ & $\begin{array}{c}\text { Total N } \\
\%\end{array}$ & $\begin{array}{c}\text { P Bray } \\
\text { ppm }\end{array}$ & K & $\mathrm{Mg}$ & $\begin{array}{c}\mathrm{Ca} \\
\mathrm{Me} 100 \mathrm{~g}^{-1} \\
\end{array}$ & $\mathrm{Na}$ & $\mathrm{Al}+\mathrm{H}$ & Sand & $\begin{array}{c}\text { Silt } \\
\%\end{array}$ & Clay \\
\hline 4.8 & 2.2 & 0.22 & 6.78 & 0.64 & 1.87 & 5.85 & 0.21 & 1.00 & 40 & 52 & 8 \\
\hline
\end{tabular}

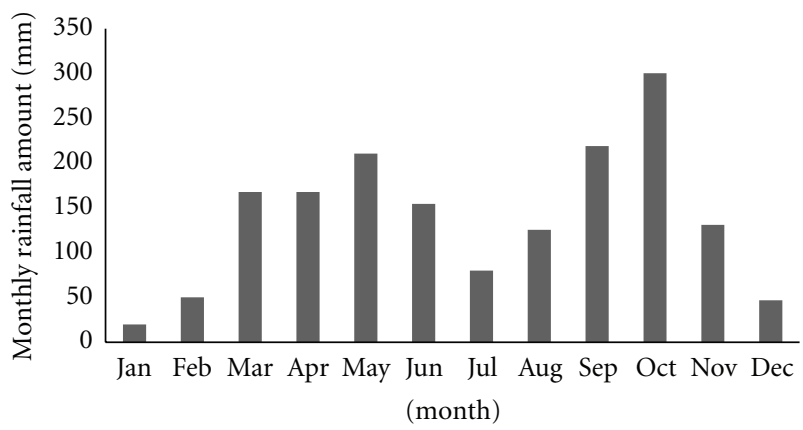

FIGURE 1: Monthly rainfall distribution at the study site during the experimental period.

years, there has been a growing interest in the tropical world in using crop residues for improving soil productivity in order to reduce the use of external inputs of inorganic fertilizers [10-12]. Moreover, there is abundance of palm bunch ash in the oil palm belt of southern Ghana where the present study was carried. These reasons necessitated the need to research into the possible use of palm bunch ash as liming material and fertilizer supplement for improving the productivity of staple food crops grown in this region. The objective of this study was to investigate the effect of palm bunch ash and NPK fertilizer on the yield and nutrient content of maize (Zea mays) and soil chemical properties in the semi-deciduous forest zone of Ghana.

\section{Materials and Methods}

2.1. Study Site. The study was carried out at the Forest and Horticultural Crops Research Centre, Kade which lies within latitude $6^{\circ} 09^{\prime}$ and $6^{\circ} 06^{\prime} \mathrm{N}$ and longitude $0^{\circ} 55^{\prime}$ and $0^{\circ}$ $49^{\prime} \mathrm{W}$ in the Kwaebibirem district of the Eastern Region of Ghana. The centre which is located in the semi-deciduous forest agro-ecological zone of Ghana is $135.9 \mathrm{~m}$ above sea level. The study site is characterized by a bimodal rainfall pattern with peaks in June and October with a short break in August and a dry season from December to March. The total annual rainfall amount during the experimental period as presented in Figure 1 was $1672.2 \mathrm{~mm}$. The soils at the experimental site which are mainly forest ochrosol derived from precambium phyllitic rocks [13] are deep and well drained and are generally classified as Acrisols in the FAOUNESCO Revised Legend [14]. The chemical and physical properties of the surface soil of the experimental plots are presented in Table 1.

2.2. Experimental Layout. The experimental plot which was dominated by Chromolaena odorata had been fallowed for
1 year. Cassava had been grown on this field earlier. The $C$. odorata was initially cleared by slashing with a cutlass. Four weeks later, herbicide (glyphosate) was applied at the rate of $900 \mathrm{~g} \mathrm{a.i} \mathrm{ha}{ }^{-1}$. The trial which was conducted in a randomised complete block design consisted of five treatments replicated four times in four blocks. The treatments which were applied to a local maize variety, Obatanpa were 0 tha $^{-1}$ PBA, 2 tha $^{-1}$ PBA, 4 tha $^{-1}$ PBA, 6 tha $^{-1}$ PBA, and $200 \mathrm{~kg}$ $\mathrm{ha}^{-1}$ NPK (15-15-15). The experiment was carried out in two seasons: the major rainy season which starts from April and ends in July and the minor rainy season which starts in August and ends in November.

In the major rainy season, the maize was planted on 25 April, 2010 at a spacing of $1 \mathrm{~m}$ by $50 \mathrm{~cm}$ at 3 seeds per hole which was thinned to 2 seeds per hole at 10 days after planting. Plot size was 15 by $5 \mathrm{~m}$ giving a plant population of 4 plants/square meter. In the minor rainy season, the plot size was 15 by $5 \mathrm{~m}$ and the maize was planted on 19 August, 2010 at $1 \mathrm{~m}$ by $20 \mathrm{~cm}$ at 3 seeds per hole which was thinned to one plant per hole 10 days after planting giving a plant population of 5 plants/square meter. The PBA was applied at 10 days after planting in a form of ring.

At tasseling, maize plant height was measured from the ground level to the point of the plant from where the tassel emerges and ear leaf samples were collected and oven-dried at $65^{\circ} \mathrm{C}$ for 3 days and milled for analysis. At maturity, maize ears and stover were harvested from the three middle rows leaving $1 \mathrm{~m}$ border at both ends. The cobs were weighed and a subsample of 10 cobs per plot was taken, weighed, and oven-dried at $70^{\circ} \mathrm{C}$ for 2 days. The grains were then removed and weighed again to determine the dry matter (DM). The stover was weighed fresh and subsample taken to determine the DM.

2.3. Leaf and Soil Analysis. Maize ear leaf samples collected at tasseling were analysed for N, P, K, Ca, and Mg. The N was determined using micro-Kjeldal method, $\mathrm{P}$ by molybdenum blue calorimetric, $\mathrm{K}$ by flame photometer, and $\mathrm{Ca}$ and $\mathrm{Mg}$ by atomic absorption spectrophotometer.

Prior to commencement of the trial, surface soil (0$20 \mathrm{~cm}$ ) samples were collected from the experimental site and analyzed for both chemical and physical properties. During the harvest, soil samples were also collected from the $0-20 \mathrm{~cm}$ depth of each plot and analyzed for soil chemical properties. Soil $\mathrm{pH}$ was determined in water suspension at $1: 1$ ratio; organic C by Walkley-Black procedure; total $\mathrm{N}$ by Kjeldahl method; available $\mathrm{P}$ by Bray- 1 method and exchangeable bases (K, Na, Ca, and Mg) by $1 \mathrm{M} \mathrm{NH} 4$ OAC method [15].

To reduce cost, only soil and ear leaf samples collected during the major rainy season planting were analysed and presented in Tables 3 and 4 , respectively. 
TABLE 2: Chemical properties of the palm bunch ash used in the experiment.

\begin{tabular}{|c|c|c|c|c|c|c|c|}
\hline \multirow[t]{2}{*}{$\mathrm{pH}$} & \multirow[t]{2}{*}{$\mathrm{OC}$} & \multirow[t]{2}{*}{ Total $\mathrm{N}$} & \multirow[t]{2}{*}{ P Bray } & \multicolumn{4}{|c|}{ Exchangeable cations } \\
\hline & & & & $\mathrm{K}$ & $\mathrm{Ca}$ & $\mathrm{Mg}$ & $\mathrm{Na}$ \\
\hline$\left(1: 2.5 \mathrm{H}_{2} \mathrm{o}\right)$ & & $\%$ & ppm & \multicolumn{4}{|c|}{ me $100 \mathrm{~g}^{-1}$} \\
\hline 10.90 & 0.55 & 0.08 & 270.27 & 583.42 & 35.24 & 29.24 & 20.51 \\
\hline
\end{tabular}

TABLE 3: Chemical properties of the $0-20 \mathrm{~cm}$ layer of the soil 110 days after application of the palm bunch ash and NPK for the major rainy season planting.

\begin{tabular}{|c|c|c|c|c|c|c|c|c|c|}
\hline & \multirow{2}{*}{$\begin{array}{c}\mathrm{pH} \\
\left(1: 1 \mathrm{H}_{2} \mathrm{o}\right)\end{array}$} & \multirow{2}{*}{$\begin{array}{c}\text { OC } \\
\%\end{array}$} & \multirow{2}{*}{$\begin{array}{c}\text { Total N } \\
\%\end{array}$} & \multirow{2}{*}{$\begin{array}{l}\text { P Bray } \\
\text { ppm }\end{array}$} & $\mathrm{K}$ & $\mathrm{Mg}$ & $\mathrm{Ca}$ & $\mathrm{Na}$ & \multirow{2}{*}{$\begin{array}{l}\mathrm{Al}+\mathrm{H} \\
\mathrm{Me} 100 \mathrm{~g}^{-1}\end{array}$} \\
\hline & & & & & \multicolumn{4}{|c|}{ Me $100 \mathrm{~g}^{-1}$} & \\
\hline 0 tha $^{-1}$ & 5.10 & 1.26 & 0.11 & 7.04 & 0.50 & 2.76 & 5.62 & 0.17 & 1.00 \\
\hline 2 tha $^{-1}$ & 5.83 & 1.57 & 0.16 & 19.77 & 1.23 & 2.63 & 4.27 & 0.19 & 0.45 \\
\hline 4 tha $^{-1}$ & 5.93 & 1.43 & 0.15 & 16.00 & 1.29 & 3.78 & 6.31 & 0.30 & 0.57 \\
\hline 6 tha $^{-1}$ & 5.90 & 1.86 & 0.17 & 22.89 & 0.76 & 3.25 & 5.07 & 0.26 & 0.50 \\
\hline NPK & 5.08 & 1.34 & 0.15 & 14.72 & 0.63 & 1.47 & 5.58 & 0.11 & 1.00 \\
\hline LSD & 0.49 & 0.78 & 0.057 & 6.63 & 0.47 & 1.48 & 2.02 & 0.07 & 0.054 \\
\hline Prob. & $1 \%$ & NS & NS & $1 \%$ & $1 \%$ & $5 \%$ & NS & $0.1 \%$ & $1 \%$ \\
\hline
\end{tabular}

2.4. Statistical Analysis. Data were subjected to analysis of variance (ANOVA) using the general linear model (GLM) procedure [16].

\section{Results and Discussion}

Results of the initial soil analysis for the experimental site are presented in Table 1. The soil of the experimental site was strongly acidic, moderately high in $\mathrm{N}$ and exchangeable $\mathrm{Ca}$ and $\mathrm{Mg}$. The PBA had pH of $10.90\left(\mathrm{H}_{2} \mathrm{O} 1: 2.5\right), 0.55 \%$ organic carbon, $0.08 \% \mathrm{~N}$ and $35.24,29.24$, and 583.42 me/100 g soil exchangeable $\mathrm{Ca}, \mathrm{Mg}$, and $\mathrm{K}$, respectively (Table 2). The $\mathrm{pH}$ value for the PBA reported in this study is significantly higher than that reported by [7] who reported a value of 8.8. The high $\mathrm{pH}$ of the PBA used in the present study could be attributed to the fact that it was a fresh ash and had not been exposed to rain. Preliminary studies carried out at Kade, Ghana shows that, when PBA is exposed to rain for a long time, the $\mathrm{pH}$ goes down (unpublished results) probably as a result of leaching of cations. The $\mathrm{pH}$ of the experimental plot at the start of the experiment was 4.8 (Table 1) compared to an average of 5.8-5.9 at 110 days after the application of PBA (Table 3). The pH of 4.8 of the soil at the start of the experiment suggests the soil to be strongly acidic according to [17] and hence, the justification for the investigation into the possible use of PBA as soil amendment.

The increase in the $\mathrm{pH}$ of the soil after the application of the PBA was due to the high pH level of the PBA. PBA is alkaline and contains relatively high values of $\mathrm{Ca}$ and $\mathrm{Mg}$ and thus has a liming effect on the soil. The increase in soil $\mathrm{pH}$ was also due to decrease in $\mathrm{Al}^{3+}$ as a result of precipitation of $\mathrm{Al}$ as hydroxyl- $\mathrm{Al}[6]$ as ash has been found to contain oxides and hydroxides of potassium, sodium, calcium, and magnesium [18] resulting in low exchangeable acidity in the ash-amended plots (Table 3). This could also be responsible for the significantly higher potassium, sodium, calcium, and magnesium levels in the PBA amended plots compared with the control [12]. The high soil OC and nutrient contents of the PBA-treated plots compared with the control plots also confirms the findings of [7] who reported significant increase in $\mathrm{OM}$ and nutrient contents of acid soils after application of PBA. The increased available P content of the soil with increased application of PBA could be attributed to release of $\mathrm{P}$ from complexes of $\mathrm{Al}$ and $\mathrm{Fe}$ under increasing soil $\mathrm{pH}$ [6]. The increase in soil nutrients as a result of application of PBA could also be attributed to increased microbial activities in the soil and increased organic matter production with its concomitant increased availability of $\mathrm{N}$, $\mathrm{P}, \mathrm{K}$, and $\mathrm{Mg}[4,19]$. Data on ear leaf analysis as shown in Table 4 indicate that compared with the control, increased application of PBA resulted in decreased leaf nutrient content except $\mathrm{P}$ and $\mathrm{K}$ which increased with application of PBA. The reduction in leaf nutrient content, especially for $\mathrm{N}, \mathrm{Mg}$, and Ca with increasing application of PBA could be attributed to excessive uptake of $\mathrm{K}[4,20]$. Table 5 shows that PBA application significantly affected the maize plant height. The least plant height of 183 and $259 \mathrm{~cm}$ in the major and minor rainy seasons, respectively, was recorded in the control plot. Relatively higher plant height was recorded in the minor rainy season.

Palm bunch ash and NPK fertiliser application increased both maize grain yield and stover yield both in the major and minor rainy seasons (Table 5). In the major rainy season fertiliser application resulted in about $100 \%$ increase in maize grain yield, while PBA application resulted in about $68-78 \%$ increase in maize grain yield over the control. In the minor rainy season mineral fertiliser application resulted in about $21 \%$ increase in maize grain yield, while PBA application resulted in between $11-22 \%$ increase in maize grain yield over the control. The highest increase in maize grain yield in both seasons was obtained at the application of 
TABLE 4: Effect of palm bunch ash and NPK fertilizer on maize ear leaf nutrient composition for the major rainy season planting.

\begin{tabular}{|c|c|c|c|c|c|}
\hline \multirow{2}{*}{ Treatment } & $\mathrm{N}$ & $\mathrm{P}$ & $\mathrm{K}$ & $\mathrm{Mg}$ & $\mathrm{Ca}$ \\
\hline & \multicolumn{5}{|c|}{$\%$} \\
\hline 0 tha $^{-1} \mathrm{PBA}$ & 2.66 & 0.25 & 0.87 & 0.19 & 0.36 \\
\hline 2 tha $^{-1} \mathrm{PBA}$ & 2.61 & 0.33 & 1.00 & 0.16 & 0.26 \\
\hline 4 tha $^{-1} \mathrm{PBA}$ & 2.59 & 0.33 & 1.00 & 0.15 & 0.26 \\
\hline 6 tha $^{-1}$ PBA & 2.56 & 0.37 & 0.98 & 0.15 & 0.23 \\
\hline NPK & 2.72 & 0.32 & 0.96 & 0.19 & 0.38 \\
\hline LSD & 0.12 & 0.05 & 0.18 & 0.04 & 0.06 \\
\hline Prob. & NS & $1 \%$ & NS & $5 \%$ & $0.1 \%$ \\
\hline
\end{tabular}

NS: not significant.

TABLE 5: Effect of PBA and NPK fertilizer on growth and yield of maize for the major and minor rainy season plantings.

\begin{tabular}{|c|c|c|c|c|c|c|}
\hline \multirow{2}{*}{ Treatment } & \multicolumn{2}{|c|}{ Plant height $(\mathrm{cm})$} & \multicolumn{2}{|c|}{ Maiza grain yield at $12 \%$ moisture content $\left(\right.$ tha $\left.^{-1}\right)$} & \multicolumn{2}{|c|}{ Maiza stover DM $\left(\right.$ tha $\left.^{-1}\right)$} \\
\hline & Major season & Minor season & Major season & Minor season & Major season & Minor season \\
\hline 0 tha $^{-1}$ PBA & 183 & 259 & 2550 & 5030 & 1990 & 2975 \\
\hline 2 tha $^{-1}$ PBA & 221 & 293 & 4530 & 6120 & 3720 & 4485 \\
\hline 4 tha $^{-1}$ PBA & 213 & 291 & 4480 & 5830 & 3470 & 3825 \\
\hline 6 tha $^{-1}$ PBA & 232 & 291 & 4290 & 5583 & 3700 & 3575 \\
\hline NPK & 234 & 284 & 5120 & 6060 & 4430 & 4743 \\
\hline LSD & 21.0 & 15.0 & 1140 & 763 & 670 & 1076 \\
\hline Prob. & $0.1 \%$ & $1 \%$ & $1 \%$ & $5 \%$ & $0.1 \%$ & $5 \%$ \\
\hline
\end{tabular}

2 tons $\mathrm{ha}^{-1} \mathrm{PBA}$. The increase in maize grain yield and root yield of cassava with PBA or Wood ash has been reported by several workers $[6,7,12,19-21]$ who attributed it to increase in soil nutrient content and uptake of nutrients by maize as well as higher organic matter in the ash.

\section{Conclusions}

The results of this study suggest that $\mathrm{pH}$ of acid soils can be corrected and leached nutrients replaced by recycling of palm bunch ash. Application of PBA contributes to improvement in soil chemical properties of acid soils by raising soil $\mathrm{pH}$ and the level of macronutrients such as $\mathrm{N}, \mathrm{P}, \mathrm{K}, \mathrm{Ca}$, and $\mathrm{Mg}$ in the soil. This may enhance yield of crops through improved nutrient uptake by crops. In both seasons, application of 2 tha ${ }^{-1}$ gave the highest maize grain yield. Thus in oil palm growing areas in Ghana, where soils are acidic, palm bunch ash which are found in abundance in these areas could be used as a liming material and as a fertiliser supplement to improve the yield of staple food crops.

\section{Acknowledgment}

The author gratefully acknowledges the financial contribution made towards this work by the Forest and Horticultural Crops Research Centre, Kade of the Institute of Agricultural Research, University of Ghana, Legon.

\section{References}

[1] K. H. Lim and A. R. Zaharah, "Decomposition and N and K release by oil palm empty fruit bunches applied under mature palms," Journal of Oil Palm Research, vol. 12, pp. 55-62, 2000.

[2] FAO Statistical Databases, 2009, http://faostat.fao.org/site/ 639/default.aspx.

[3] J. Opoku and F.A. Asante, "Palm oil production in Ghana," Final report on the status of the oil palm industry in Ghana, German Technical Co-operation (GTZ), Accra, Ghana, 2008.

[4] A. Saarsalmi, E. Mälkönen, and S. Piirainen, "Effects of wood ash fertilization on forest soil chemical properties," Silva Fennica, vol. 35, no. 3, pp. 355-368, 2001.

[5] B. P. Bougnom, J. Mair, F. X. Etoa, and H. Insam, "Composts with wood ash addition: a risk or a chance for ameliorating acid tropical soils?" Geoderma, vol. 153, no. 3-4, pp. 402-407, 2009.

[6] C. N. Mbah, J. N. Nwite, C. Njoku, and I. A. Nweke, "Response of maize (Zea mays L.) to different rates of wood-ash application in acid ultisol in Southeast Nigeria," African Journal of Agricultural Research, vol. 5, no. 7, pp. 580-583, 2010.

[7] M. A. Awodun, S. O. Ojeniyi, A. Adeboye, and A. S. Odedina, "Effect of oil palm bunch refuse ash on soil and plant nutrient composition and yield of maize," Eurasian Journal of Sustainable Agriculture, vol. 1, pp. 50-54, 2007.

[8] S. O. Ojeniyi, P. O. Ezekiel, D. O. Asawalam, A. O. Awo, S. A. Odedina, and J. N. Odedina, "Root growth and NPK status of cassava as influenced by oil palm bunch ash," African Journal of Biotechnology, vol. 8, no. 18, pp. 4407-4412, 2009. 
[9] H. Gerner, E. O. Asante, E. Owusu Benoah, and K. Marfo, Ghana Fertilizer Privatization Scheme. Private Sector Role and Public Sector Responsibility in Meeting Needs of Farmers, IFDCAfrica, Lome, Togo, 1995.

[10] H. Khalid, Z. Zin, and T. M. Anderson, "Nutrient cycling in an oil palm plantation. The effects of residue management practices during replanting on dry matter and nutrient uptake of young palms," Journal of Oil Palm Research, vol. 12, pp. 2937, 2000.

[11] L. S. Ayeni, O. M. Ayeni, O. P. Oso, and S. O. Ojeniyi, "Effect of sawdust and wood ash applications in improving soil chemical properties and growth of cocoa (Theobroma cacao) seedlings in the nurseries," Medwel Agricultural Journal, vol. 3, pp. 323$326,2008$.

[12] F. O. Adekayode and M. R. Olojugba, "The utilization of wood ash as manure to reduce the use of mineral fertilizer for improved performance of maize (Zea mays L.) as measured in the chlorophyll content and grain yield," Journal of Soil Science and Environmental Management, vol. 1, pp. 40-45, 2010.

[13] P. M. Ahn, "Soils of the lower tano basin, South Western Ghana," Ghana Ministry of Food and Agriculture, Soils and Landuse Survey Memoir No. 2, 1961.

[14] F.A.O., "FAO Unesco Soil Map of the world," World Soil Resources Report, vol. 60, FAO, Rome, Italy, 1998.

[15] Agronomy Society of America-Soil Science Society of America, Methods of Soil Analysis, Part 2, Chemical and Microbiological Properties-Agronomy Monograph No. 9, ASA-SSA, Madison, Wis, USA, 2nd edition, 1982.

[16] SAS, SAS User's Guide: Statistics, SAS Institute, Cary, NC, USA, 1996.

[17] N. C. Brady, The Nature and Properties of Soils, Macmillan, New York, NY, USA, 9th edition, 1984.

[18] A. Demeyer, J. C. Voundi Nkana, and M. G. Verloo, "Characteristics of wood ash and influence on soil properties and nutrient uptake: an overview," Bioresource Technology, vol. 77, no. 3, pp. 287-295, 2001.

[19] S. O. Ojeniyi, B. C. Awanlemhen, and S. A. Adejoro, "Soil plant nutrients and maize performance as influenced by oilpalm bunch ash plus NPK fertilizer," Journal of American Science, vol. 6, no. 12, pp. 456-460, 2010.

[20] U. S. Offor, G. I. Wilcox, and C. N. Agbagwaa, "Potentials of palm bunch ash on yield of Zea mays," Journal of Agriculture and Social Research, vol. 10, no. 2, pp. 132-134, 2010.

[21] P. O. Ezekiel, S. O. Ojeniyi, D. O. Asawalam, and A. O. Awo, "Root growth, dry root yield and NPK content of cassava as influenced by oil palm bunch ash on ultisols of southeast Nigeria," Nigerian Journal of Soil Science, vol. 19, pp. 6-10, 2009. 

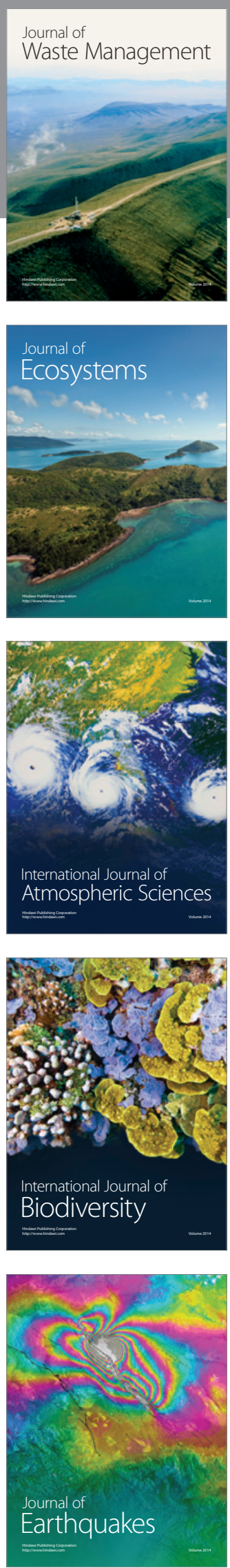
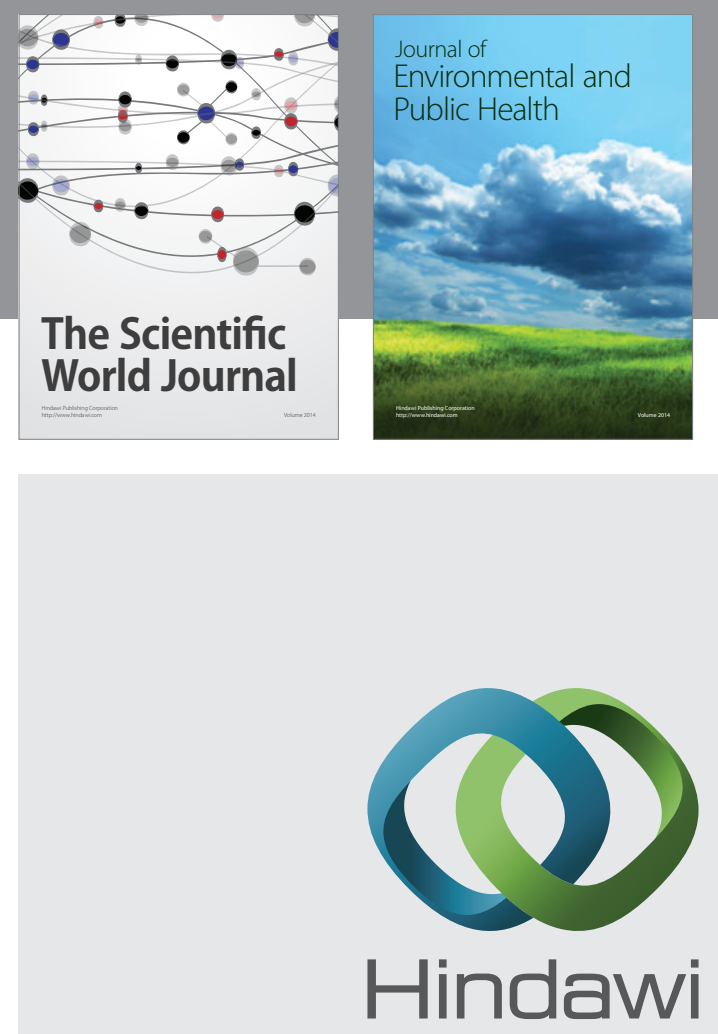

Submit your manuscripts at

http://www.hindawi.com
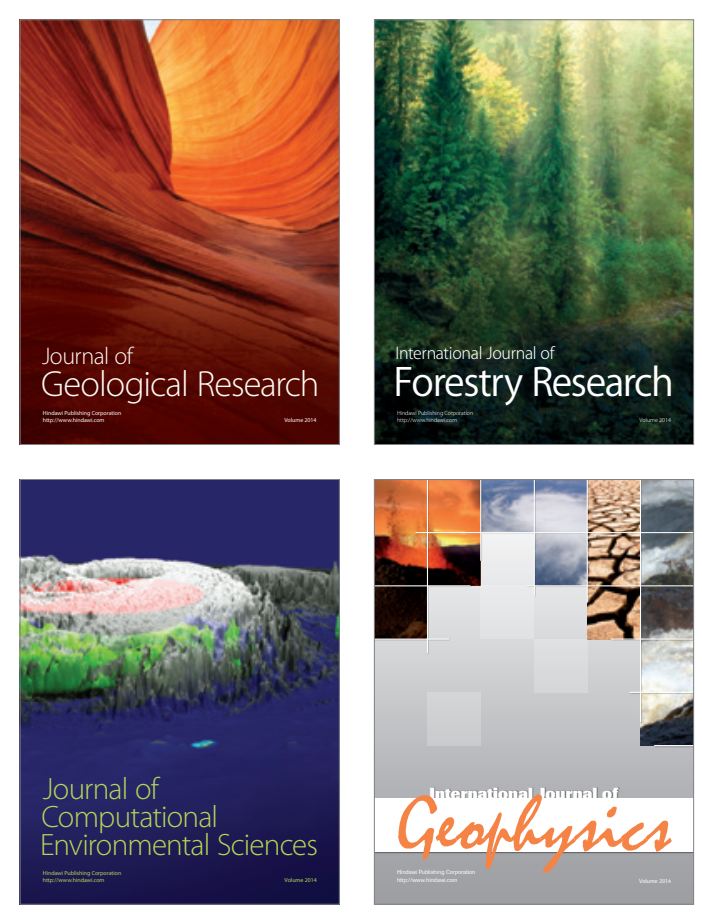
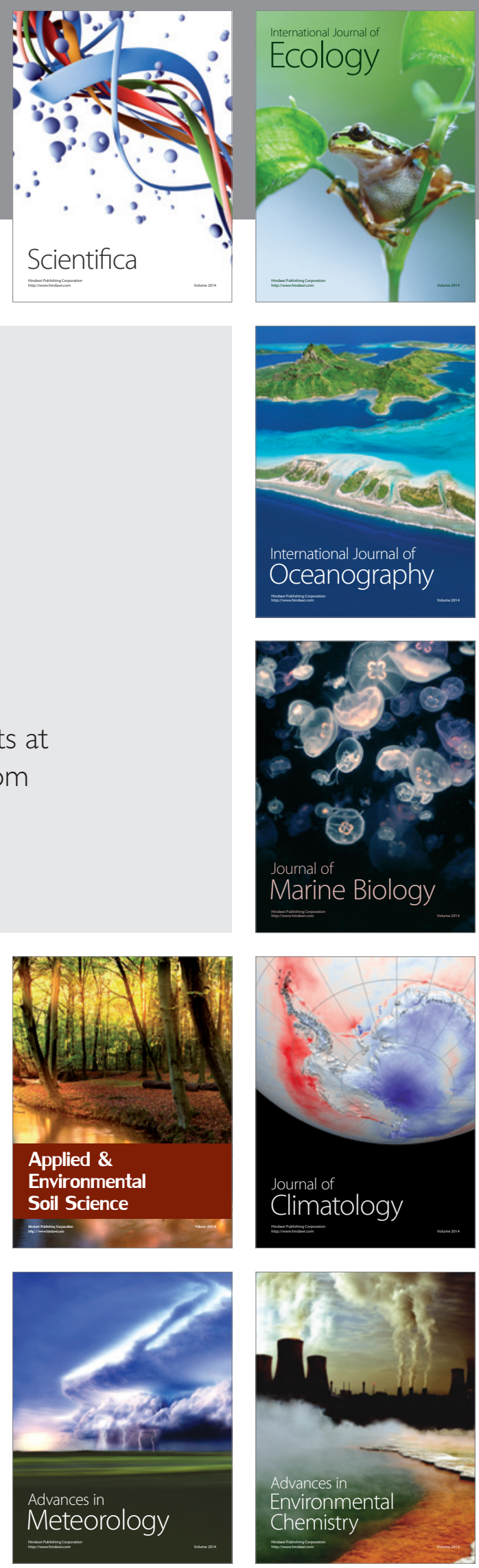